\title{
Nuclear Pore Changes and Absence of Apoptosis in Lumbar Dorsal Root Ganglion Neurons of Doxorubicin-Intoxicated Rats
}

\author{
Man-fu Han, Qiu-yue Her, Akio OHnishi, Tatsunori Yamamoto, \\ Hideyuki HashiguaHI and Yoshiyuki MURAI \\ Department of Neurology, School of Medicine, University of Occupational and Environmental Health, \\ Japan. Yahatanishi-ku, Kitakyushu 807-8555, Japan
}

Abstract: Doxorubicin (DXR) produces degeneration of neurons in the lumbar dorsal root ganglion (DRG) in rats. Light microscopic studies, which included the terminal deoxynucleotidyl transferase-mediated deoxyuridine triphosphate-biotin nick end labeling method, and electron microscopic observation revealed that the moderate nuclear and remarkable cytoplasmic degeneration of DRG neurons of Sprague-Dawley rats after intravenous administration of $8 \mathrm{mg} / \mathrm{kg}$ of DXR was cell necrosis, not apoptosis. In some neurons, mostly dark and usually with moderate degrees of nuclear degenerative changes, the nuclear pores were decreased in number and obscure 14 and 20 days after DXR administration. DXR enters presumably the nucleus and is partly removed through the nuclear pores. However, the diameters of nuclear pores were similar in DXR-intoxicated and control rats. The changes in nuclear pores of neurons in DXR intoxication, which to our knowledge has not been previously studied, are considered to be part of the degenerative or necrotic changes of DRG neurons.

Key words : doxorubicin, dorsal root ganglion neuron, nuclear pore, cell necrosis, apoptosis.

(Received 3 October 1997, accepted 4 March 1998)

\section{Introduction}

The nuclear pore complex is a large supramolecular assembly embedded in the inner and outer nuclear membranes which plays an important role in nucleocytoplasmic transport $[1-4]$. On transmission electron microscopy, neuronal nuclear pores are best observed as dark circles approximately $90 \mathrm{~nm}$ in outer diameter embedded in a fine, grainy mist, which represents the membranous component of the nuclear envelope [4]. Doxorubicin (DXR), an anthracycline antibiotic, causes degeneration of lumbar dorsal root ganglion 
(DRG) neurons in rats $[5-9]$. The action site of DXR is the cell nucleus, where DXR breaks down DNA [8]. We studied nuclear pore changes in DXR-induced DRG neuronal degeneration. Such a study has not been reported in the literature, to our knowledge. Furthermore, because DXR causes apoptosis of various cell types in vitro $[10-12]$, we also studied whether DXR-induced neuronal degeneration is due to apotosis.

\section{Materials and Methods}

Forty male Sprague-Dawley rats weighing 220 to $280 \mathrm{~g}$ were divided into 4 groups : 3 experimental groups and 1 control group. The 10 rats of each group were anesthetized with intraperitoneal pentobarbital. In the three experimental groups, single intravenous injections of DXR, $8 \mathrm{mg} / \mathrm{kg}$ of body weight, were given in the right neck vein. In the control group, only saline was given in a similar manner. Ten days (experimental group 1), 14 days (experimental group 2), and 20 days (experimental group 3) after the injection, the rats were perfused through the left cardiac ventricle with $3 \%$ glutaraldehyde in $0.05 \mathrm{M}$ cacodylate buffer $(\mathrm{pH}$ 7.4) at room temperature. Control rats were also sacrificed on the same days. After perfusion fixation, the dorsal root ganglia at the 5th and 6th lumbar segments bilaterally were harvested and fixed in the same fixative for an additional 3 hours. Each ganglion was cut into four blocks perpendicularly to the long axis, washed, and postfixed with aqueous $1 \%$ osmium tetroxide solution for 3 hours. After dehydration in graded ethanol and immersion in propylene oxide, the specimens were embedded in epoxy resin. Sections, perpendicular to the long axis of the ganglion and $1 \mu \mathrm{m}$ in thickness, were cut and stained with toluidine blue for light microscopy. After light microscopic examination, ultrathin sections were cut, stained with uranyl acetate and lead citrate, and examined with a JEM-1200 EX II electron microscope (JEOL, Tokyo, Japan). On electron microscopy, sections passing tangentially through the nuclear envelope were photographed selectively at magnifications of 15,000 and 40,000 times. The lesser outer diameter of the nuclear pore was measured on electron micrographs with more than 15 well-visualized nuclear pores with the final magnification of 100,000 times. The mean nuclear pore diameters in each of the experimental groups and the control group were obtained and compared by using the Student's and Welch's t-test. Electron micrographs of the sections perpendicular to the nuclear envelope were also taken to examine the nuclear pore and its diaphragm [4].

In a separate experiment, 20 male Sprague-Dawley rats weighing $250 \mathrm{~g}$, were divided into 5 equal groups: 4 experimental groups and 1 control group. Four rats in each experimental group were given $8 \mathrm{mg} / \mathrm{kg}$ of DXR intravenously as 
described above. In the control group, only saline was given. This experiment was designed to study apoptotic nuclear alterations preceding to the remarkable cytoplasmic changes on days 10, 14 and 20 after DXR injection. One day (experimental group 1), 3 days (experimental group 2), 7 days (experimental group 3), and 14 days (experimental group 4) after injection, the rats were perfused through the left cardiac ventricle with an aqueous $4 \%$ paraformaldehyde solution freshly prepared $(\mathrm{pH} \mathrm{7.4)}$ at room temperature. Control rats were also sacrificed on the same days as the experimental groups. After perfusion fixation, bilateral DRGs of the 4th, 5th, and 6th lumbar segments were harvested and fixed in the same fixative for an additional 48 hours. Ganglia from the right side of each rat were dehydrated with ethanol and immersed in xylene and embedded in paraffin. Sections 4 to $6 \mu \mathrm{m}$ thick were placed on slides pretreated with a $0.01 \%$ aqueous solution of poly-L-lysine. To study the incidence of apotosis induced by DXR administration, terminal deoxynucleotidyl transferase-mediated deoxyuridine triphosphate-biotin nick end labeling (TUNEL) [13] was applied to the deparaffinized and hydrated sections. The percentage of neurons which showed positive reactions with the TUNEL method was calculated for each rat.

Ganglia from the left side were processed for confocal laser scanning microscopy with autofluorescence of DXR in the experimental groups 1, 2 and 3 (1,3 and 7 days, respectively) and the control groups, which were excited with the 488-nm line from an argon laser. On confocal laser scanning microscopy (Zeiss, Germany), the sites of positive fluorescence were qualitatively evaluated and characterized.

All observations, evaluations and measurements of the two experiments were performed without knowledge of the group to which the rat belonged.

\section{Results}

On light microscopy of the lumbar dorsal root ganglion neurons 14 days after DXR injection, cytoplasmic changes, such as an increase of dense bodies (Fig. 1A) and vacuoles of various sizes (Fig. 1B), and nuclear changes, such as eccentricity and irregular contour (Fig. 1A and 1B) were observed. On day 10 such changes were less frequently found than on day 14 and day 20. The frequency of such changes seemed to be similar between on day 14 and on day 20 .

Fourteen days after DXR injection, on combined light and electron microscopy, both nuclear and cytoplasmic abnormalities were well characterized. Nuclear abnormalities consisted of eccentricity, irregular contour, and focal aggregation or focal loss of chromatin (Fig. 2A). Gytoplasmic abnormalities consisted of an increase of dense bodies (Fig. 2B), masses of neurofilaments (Fig. 


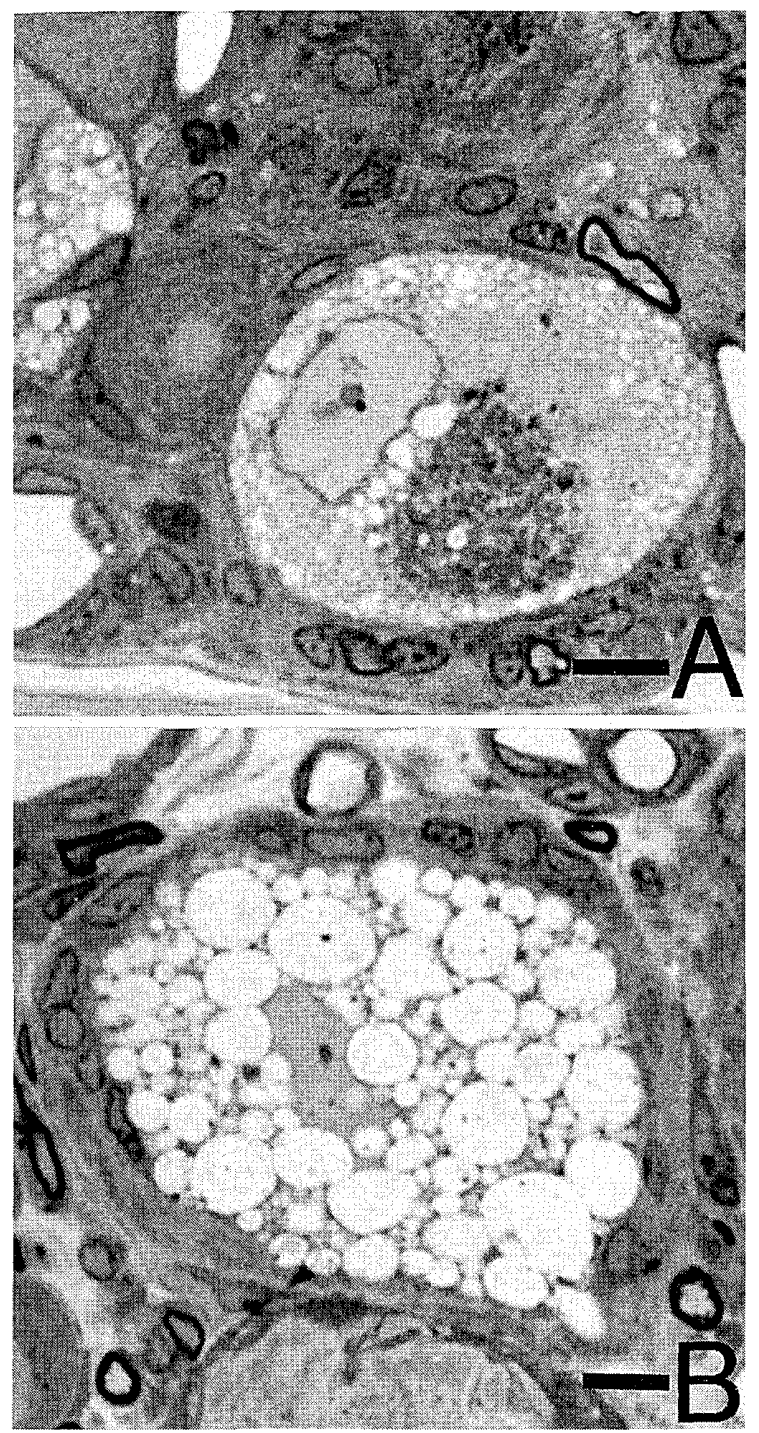

Fig. 1. Light micrographs of the lumbar dorsal root ganglion neurons fourteen days after DXR injection. In the cytoplasm, an increase of dense bodies $(A)$ and vacuoles $(A$ and $B$ ) is obvious. The nucleus shows the irregular contour (A and B) and eccentricity (A). In A, a normal-looking dark neuron is found, and in B, a part of a normal-looking light neuron can bee seen. Bar indicates $10 \mu \mathrm{m}$ in $\mathrm{A}$ and $\mathrm{B}$.

2C), and vacuoles (Fig. 2D) were observed. Both nuclear and cytoplasmic abnormalites were present in some neurons. Nevertheless in most such neurons, cytoplasmic changes were more marked than were nuclear changes. The frequency of cytoplasmic abnormalities was similar, approximately $10 \%$, in light, intermediate, and dark neurons, but, the frequency of nuclear abnormalities was higher (approximately 15\%) in light neurons than in intermediate or dark neurons (approximately $5 \%$ ). On day 10, the above definite cytoplasmic and nuclear changes were less frequently observed in some light, intermediate and dark neurons than on days 14 and 20. The frequencies of cytoplasmic and nuclear changes were almost similar between on day 14 and 20. However, on day 20, 

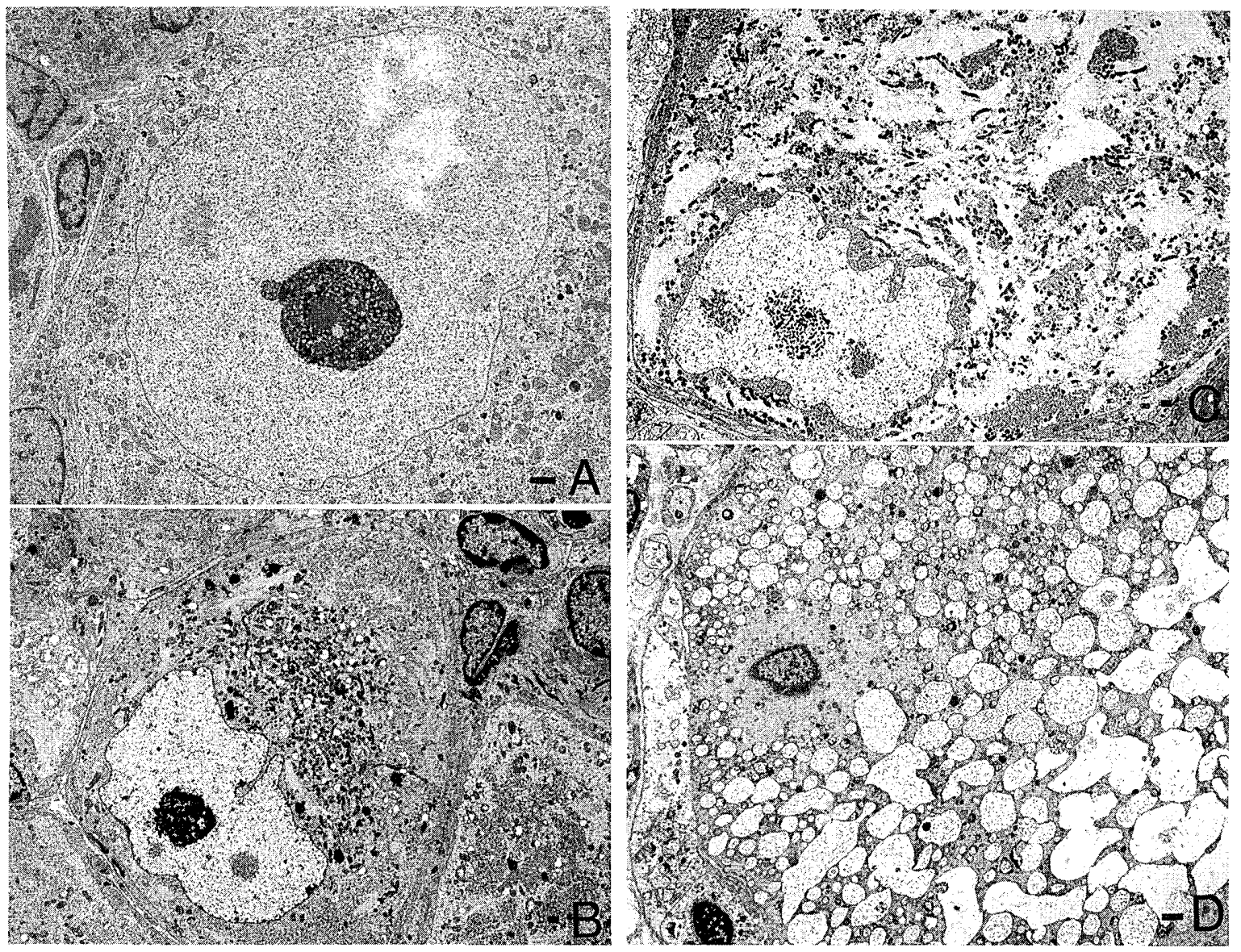

Fig. 2. Electron micrographs of the lumbar dorsal root ganglion neurons fourteen days after DXR injection. Focal loss of nuclear chromatin (A), increase of dense bodies, mitochondria and vacuoles in the cytoplasm with eccentric nucleus (B), increase of the mass of neurofilaments with eccentric nucleus (C) and increase of vacuoles with various sizes (D) are shown. Bar indicates $1 \mu \mathrm{m}$ in $\mathrm{A}, \mathrm{B}, \mathrm{C}$ and $\mathrm{D}$.

the changes were more severe than on day 14 and some neurons had disappeared. Signs of apoptosis $[14,15]$, condensed, cup-shaped, marginated chromatin at the nuclear membrane, nuclear fragmentation and spreading of fragmented nuclei, micronuclei, were not observed despite careful, repeated observation of all types of neurons 10, 14, and 20 days after DXR injection.

The nuclear pores were observed most frequently in dark neurons. finding reflected the higher frequency of tangential sectioning of the nuclei of small neurons. In 5 of 25 sections passing tangentially through the nucleus in each of the experimental groups 2 (on day 14) and 3 (on day 20), the nuclear pores had partially or almost totally disappeared and had become obscured, leaving a fine, dark, grainy mist (Fig. 3B), different from 20 similar sections in the control group (Fig. 3A) and experimental group 1 (on day 10). These changes in nuclear pores were occasionally associated with moderate focal aggregation or focal loss of 

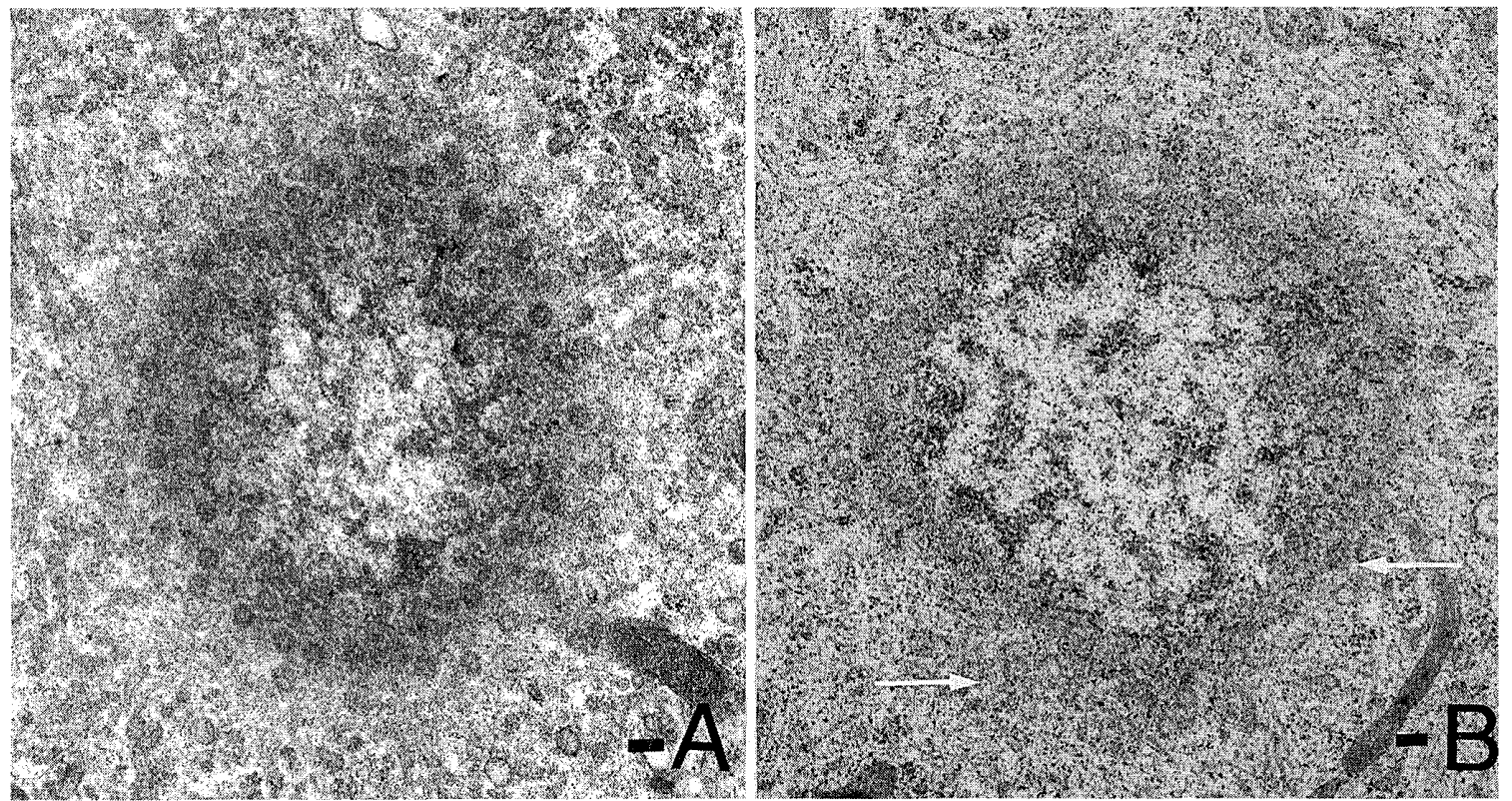

Fig. 3. The section passing tangentially through the plane of the nuclear envelope of a dark neuron. In the control group (A), nuclear pores are dark circles embedded in a fine, grainy mist. Their circular boundaries and the circular nuclear membrane boundary are obvious. In the experimental group, fourteen days after DXR injection (B), nuclear pores were much fewer in number and less prominent (arrows) than in the control group. The pores are unevenly distributed. The nuclear membrane boundary is irregular and unclear. Bar indicates $0.1 \mu \mathrm{m}$ in $\mathrm{A}$ and $\mathrm{B}$.

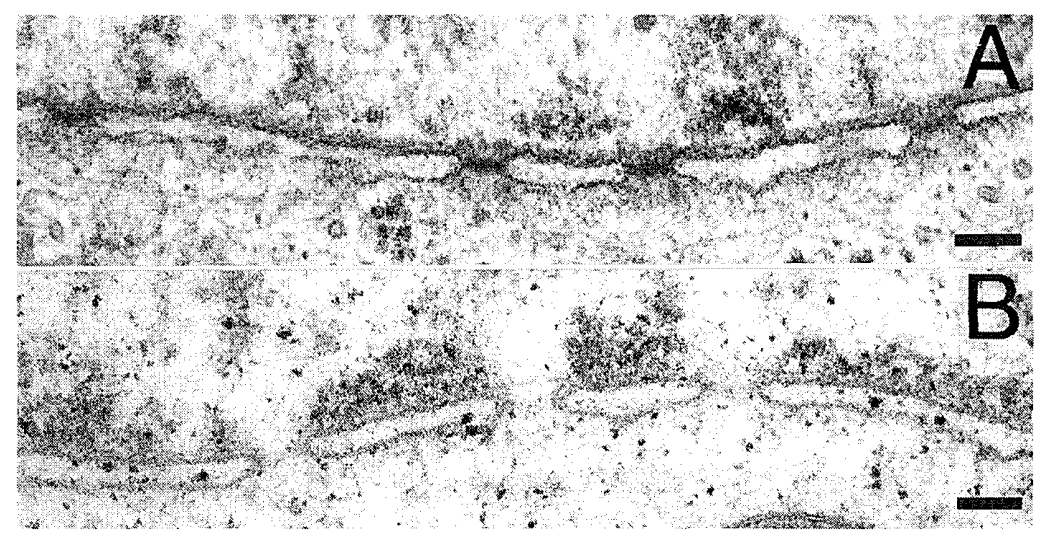

Fig. 4. The section perpendicular to the nuclear envelope of a dark neuron. In the experimental group fourteen days after DXR injection (B), nuclear pore diaphragms are less dense than those in the control group (A). Bar indicates $0.1 \mu \mathrm{m}$.

nuclear chromatin and were frequently associated with irregular nuclear membrane profiles. The mean outer diameters of nuclear pores that were clearly identified in the control group and in experimental groups 1 (on day 10), 2 (on day 14), and 3 (on day 20) were $96.0 \pm 4.0 \mathrm{~nm}$ (Mean $\pm \mathrm{SD}, 140$ pores in 7 nuclei), $94.5 \pm 4.0 \mathrm{~nm}$ (120 pores in 6 nuclei), $95.2 \pm 4.0 \mathrm{~nm}$ (110 pores in 7 nuclei), and $95.4 \pm 3.3 \mathrm{~nm}$ (140 pores in 7 nuclei), respectively. The mean 
diameters did not differ significantly between the control group and each of the experimental groups. In sections perpendicular to the nuclear envelope, nuclear pores were less often observed than in those passing tangentially to the nuclei. Nuclear pore diaphragms were less dense (Fig. 4B) in some neurons in experimental groups 2 (on day 14) and 3 (on day 20) than in the control group (Fig. 4A) and experimental group 1 (on day 10).

The TUNEL method [13] did not reveal a distinctive pattern of nuclear

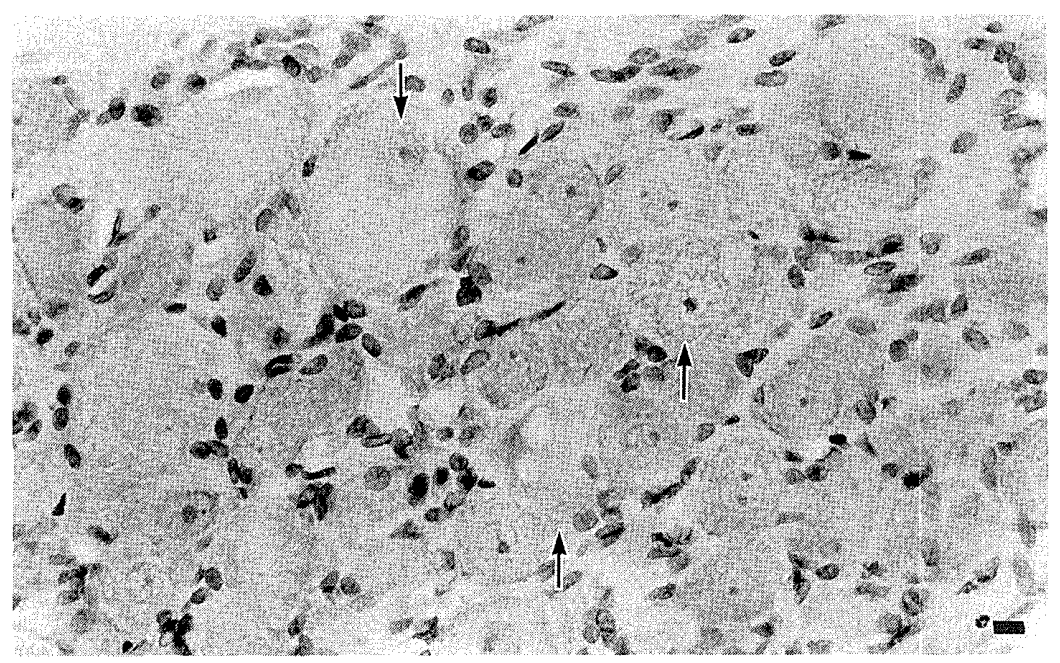

Fig. 5. A light micrograph of the lumbar dorsal root ganglion seven days after DXR injection. The nuclei of normal-looking neurons and those showing cytoplasmic abnormality with eccentric nuclei (arrows) are negative with the TUNEL method. Bar indicates $10 \mu \mathrm{m}$.

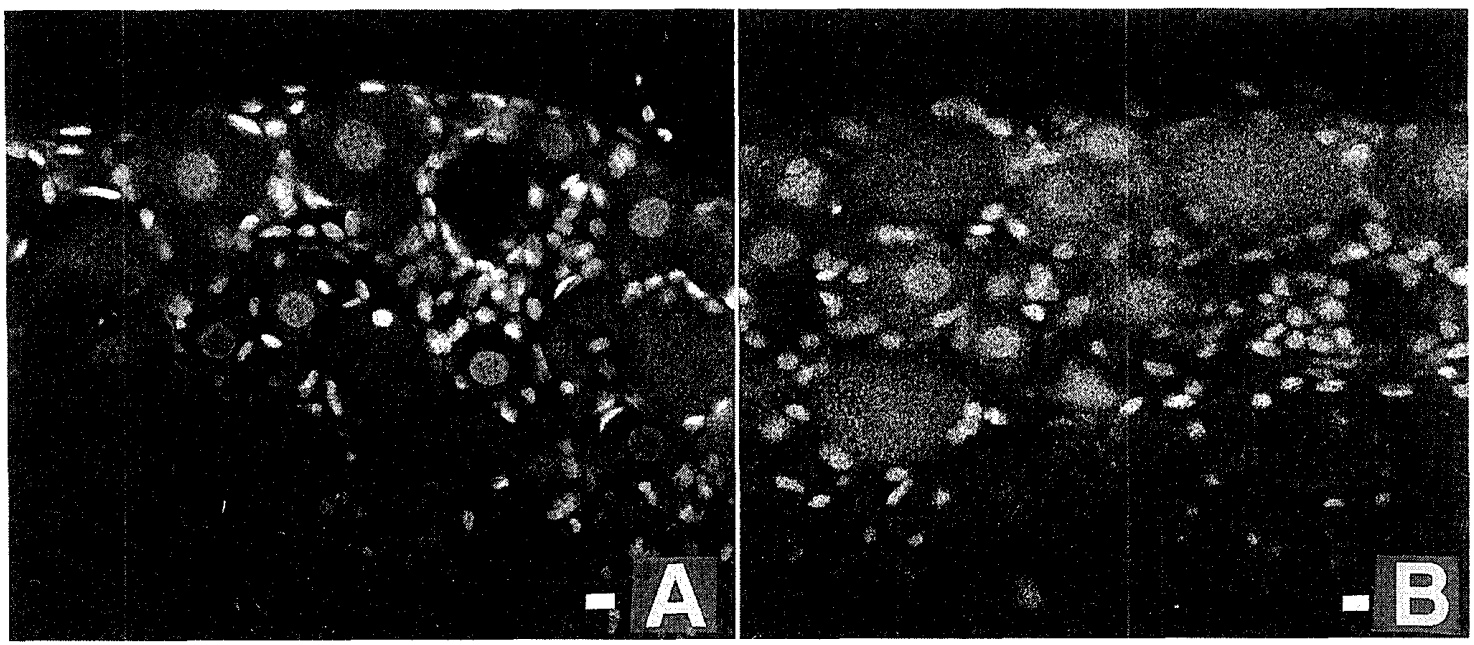

Fig. 6. Confocal laser scanning micrographs of the lumbar dorsal root ganglion of the experimental groups 1 (A) and 2 (B), day 1 and 3, respectively, after DXR injection. No fragmented nuclei with fluorescence is observed. The fluorescence of DXR is positive in the nuclei of both neurons and capsular cells (A and B). It is moderately and diffusely positive in the neuronal cytoplasm in $\mathrm{B}$, but not in $\mathrm{A}$. Bar indicates $10 \mu \mathrm{m}$. 
staining of capsular cells and light, intermediate, and dark neurons in DRGs in either the control group or in the three experimental groups (on days 3, 7 and 14). Staining was negative (Fig. 5) in both degenerating and normal-appearing neurons.

On confocal laser scanning microscopy, the fluorescence of DXR was strongly positive in nuclei of light, intermediate, and dark neurons and capsular cells in experimental groups 1 (on day 1 after injection, Fig. 6A), and 2 (on day 3, Fig. 6B). No fragmented nuclei with fluorescence were observed in experimental groups 1 (on day 1), 2 (on day 3), and 3 (on day 7). In the neuronal cytoplasm, the fluorescence was negative in the experimental group 1 (on day 1 , Fig. 6A), but it was moderately and diffusely positive in the experimental group 2 (on day 3 , Fig. 6B). The fluorescence was faint diffusely in both degenerating and normal-appearing neurons and capsular cells, and the nuclei of neurons and capsular cells were not discernible in the experimental group 3 (on day 7). No such nuclear fluorescence was observed in any corresponding control group.

\section{Discussion}

After DXR is administered intravenously in rats, it enters the spinal sensory ganglia, reaches the ganglion neurons, and causes them to degenerate $[5-9]$. The mode of action of DXR is thought to be intercalation with DNA which induces breakage of the helical structures [8]. The nuclear pore is the route through which DXR enters and is partially removed. The changes in nuclear pores in various pathologic conditions are scanty in the literature and those in DXR-induced neuronal degeneration have not, to our knowledge, been reported. For observation of nuclear pores, the site and plane of a section and the size of the nucleus are critical. The nuclear pore is observed clearly when viewed en face, sectioned tangentially through the nuclear envelope, or when viewed perpendicular to the plane of the nuclear envelope. Therefore, such observation is time-consuming. Furthermore, we could only observe significant numbers of nuclear pores mostly in dark neurons, judging from the adjacent semiserial light microscopic sections in some epon blocks.

In this experiment, abnormalities of nuclear pores consisted of a partial or almost total disappearance of nuclear pores and a decrease in the density of its diaphragm, mostly in the dark neurons, which were observed 14 and 20 days, but not 10 days, after DXR intoxication. The abnormalities were associated with moderate nuclear changes, such as mild focal aggregation or focal loss of chromatin and a less circular profile, but usually with marked degeneration of the cytoplasm. Therefore, we interpret such nuclear pore abnormalities as degenerative changes of the nucleus associated with moderate nuclear and 
remarkable cytoplasmic degeneration mostly in dark neurons. The neuropathologic significance of nuclear pore abnormalities is unknown; therefore, they should be also studied under other pathologic conditions affecting spinal sensory neurons, such as methylmercury and pyridoxine intoxication [16-18]. DXR produces apoptosis in various cell types in vitro [10-12]. Under our experimental conditions in vivo, no findings suggesting the presence of apoptosis $[14,15]$ were obtained with electron microscopy, TUNEL, or confocal fluorescent microscopy. Therefore, we conclude that apoptosis was not produced by DXR under our experimental conditions. In addition, our review of previous electron micrographic studies of DRG neuronal degeneration also found no evidence of apoptosis. The causes and mechanisms of the differences in the type of cell degeneration produced by DXR in vivo and in vitro remain unknown.

\section{Acknowledgments}

The authors acknowledge the technical assistance of R. Kaku, M. Kawamoto, and Y. Fuchigami. This study was supported in part by Grant (7B-1-06) for nervous and mental disorders from the Ministry of Health and Welfare, Japan.

\section{References}

1. Jarnik M \& Aebi U (1991): Toward a more complete 3-D structure of the nuclear pore complex. J Struct Biol 107: 291-308

2. Goldberg MW \& Allen TD (1993): The nuclear pore complex: three-dimensional surface structure revealed by field emission, in-lens scanning electron microscopy, with underlying structure uncovered by proteolysis. J Gell Sci 106: 261-274

3. Hinshaw JE (1994): Architecture of the nuclear pore complex and its involvement in nucleocytoplasmic transport. Biochem Pharmacol 47: 15-20

4. Peters A, Palay SL \& Webster H deF (1991): The nucleus. In: The Fine Structure of the Nervous System. Neurons and Their Supporting Cells. 3rd. ed. Oxford University Press, New York pp 48-64

5. Cho E-S (1977): Toxic effects of Adriamycin on the ganglia of the peripheral nervous system-a neuropathological study. J Neuropathol Exper Neurol 36: 907-915

6. Ohnishi A (1979): Primary sensory neurons in experimental adriamycin intoxication. Neurol Med (Tokyo) 10: 378-385

7. Cho ES, Spencer.PS, Jortner BS \& Schaumburg HH (1980): A single intravenous injection of doxorubicin (Adriamycin ${ }^{(\mathbb{R})}$ ) induces sensory neuropathy in rats. Neurotoxicology 1: $583-591$

8. Cho E-S, Spencer PS \& Jortner BS (1980): Doxorubicin. In: Experimental and Clinical Neurotoxicology. (Spencer PS \& Schaumburg HH, ed). Williams \& Wilkins, Baltimore pp 430-439

9. Eddy EL \& Nathaniel EJH (1982): An ultrastructural study of the effects of adriamycin on the dorsal root ganglia of young and adult rats. Exp Neurol 77: 275-285 
10. Ling Y-H, Priebe W \& Perez-Soler R (1993): Apoptosis induced by anthracycline antibiotics in P388 parent and multidrug-resistant cells. Cancer Res 53: 1845-1852

11. Skladanowski A \& Konopa J (1993): Adriamycin and daunomycin induce programmed cell death (apoptosis) in tumor cells. Biochem Pharmacol 46: 375-382

12. Jaffrézou J-P, Levade T, Bettaïeb A, Andrieu N, Bezombes C, Maestre N, Vermeersch S, Rousse A \& Laurent G (1996): Daunorubicin-induced apoptosis: triggering of ceramide generation through sphingomyelin hydrolysis. EMBO J 15: 2417-2424

13. Gavrieli Y, Sherman Y \& Ben-Sasson SA (1992): Identification of programmed cell death in situ via specific labeling of nuclear DNA fragmentation. J Cell Biol 119: 493-501

14. Falcieri E, Gobbi P, Zamai L \& Vitale M (1994): Ultrastructural features of apoptosis. Scanning Microsc 8: 653-666

15. Dini L, Coppola S, Ruzittu MT \& Ghibelli L (1996): Multiple pathways for apoptotic nuclear fragmentation. Exp Cell Res 223: 340-347

16. Chang LW (1980): Mercury. In: Experimental and Clinical Neurotoxicology. (Spencer PS \& Schaumburg HH, ed). Williams \& Wilkins, Baltimore pp 508-526

17. Nagashima K, Fujii Y, Tsukamoto T, Nukuzuma S, Satoh M, Fujita M, Fujioka Y \& Akagi H (1996): Apoptotic process of cerebellar degeneration in experimental methylmercury intoxication of rats. Acta Neuropathol 91: 72-77

18. Yamamoto $T$ (1991): Pathologic processes of lumbar primary sensory neurons produced by high doses of pyridoxine in rats - Morphometric and electron microscopic studiesJ UOEH 13: 109-123 (in Japanese with English abstract) 
ドキソルビシン中毒ラットの腰部後根神経節ニューロンの アポトーシスと核膜孔の検討

韓 漫夫, 赫 秋月, 大西 晃生, 山本 辰紀, 橋口 英志, 村井 由之 産業医科大学医学部 神経内科学教室

要＼cjkstart旨： ドキソルビシン（DXR）はラットの腰部後根神経節ニューロンに変性を若起する。ア ポトーシスを示す細胞で陽性所見を示す TUNEL 法を含む光学顕微鏡学的観察およ び電子顕微鏡学的観察に捛いて，DXR $8 \mathrm{mg} / \mathrm{kg}$ の投与を受けた Sprague-Dawley ラッ トの後根神経節ニューロンに，比較的軽い核の変性所見および著明な細胞質の変性 所見が認められた。この変性所見は, 細胞壊死でアポトーシスではないと判断された. 比較的軽い核の変性所見を呈し，その大部分が darkニューロンと判断されたニュー ロンにおいて，DXR 投与 14 日および 20 日後に核膜孔が不明瞭となりその数の低下 が認められた。しかし，DXR 投与群と対照群の間で核膜孔の大きさに差は認められ なかった。DXR はこの核膜孔を通じて核内に入り一部核内から核外へ排出されると 考えられる，文献上われわれの知る限りDXR 中毒ラットのニューロンで核膜孔の変 化は検討されていないが，本実験で認められた核膜孔の変化は DXR 中毒ラットの後 根神経節ニューロンの変性または壊死所見の一部と判断された.

J UOEH（産業医大誌）20（2）：115-125 (1998) 